\title{
A RARE CASE REPORT ON MYXOEDEMA COMA
}

\author{
SHANTHI B, MARY CHANDRIKA A*
}

Department of Biochemistry, Sree Balaji Medical College and Hospital, Chennai, Tamil Nadu, India. Email: chandrikabiochem@gmail.com Received: 04 February 2019, Revised and Accepted: 06 January 2021

\begin{abstract}
Myxoedema coma is a sporadic life-threatening complication of severe hypothyroidism with high mortality. Altered mental status and hypothermia are the main symptoms of myxoedema coma. Apart from that, hypoxia, bradycardia, hypotension, anemia, and hyponatremia would be present. Few patients present comatose with severe myxoedema. Presenting coma may mislead the diagnosis of this condition. A female patient presented with fever, breathlessness, and disorientation was admitted. First diagnosed to have electrolyte imbalance and treatment was started accordingly. The patient did not show much of an improvement, and it took a day to identify the presence of severe hypothyroidism. Treating hypothyroidism resulted in an advance in the patient condition. Patients' previous history of hypothyroidism was not informed during admission. It is always tough to diagnose myxoedema coma when the patients' previous history of hypothyroidism is unknown. Hence, it is still essential to have hypothyroidism in mind while treating patients with comatose. This case has been reported to alert physicians in diagnosing myxoedema coma patients and to proceed with the treatment at the earliest.
\end{abstract}

Keywords: Myxoedema coma, Hypothyroidism, Hyponatremia.

(C) 2021 The Authors. Published by Innovare Academic Sciences Pvt Ltd. This is an open access article under the CC BY license (http://creativecommons.org/ licenses/by/4.0/) DOI: http://dx.doi.org/10.22159/ajpcr.2021v14i3.32401. Journal homepage: https://innovareacademics.in/journals/index.php/ajpcr

\section{BACKGROUND}

Myxoedema coma is a scarce form of severe hypothyroidism with very high mortality of $50-60 \%$ [1]. When hypothyroidism has not been treated properly, it will result in many physiological decompensations such as hypoxia, bradycardia, hypotension, anemia, hyponatremia, and hypoventilation [2-5]. Drugs, infection, hypothermia, and other systemic condition act as the triggering point for this condition in patients with severe untreated hypothyroidism [6]

\section{CASE REPORT}

A 51-year-old female was brought to Sree Balaji Medical College and Hospital casualty with complaints of difficulty to breath, bilateral leg swelling, fever for 5 days, and drowsiness for 1 day. Patient did not have previous history of medical illness such as diabetes mellitus, hypertension, hypothyroidism, and seizure disorder. Her previous drug history (if any) was not known.

Her general examination, the patient was drowsy, obeying simple commands, dyspneic at rest, mild pallor and facial puffiness present, bilateral pitting pedal edema noticed, peripheries were very cold to touch with a capillary refill of more than $5 \mathrm{~s}$, no clubbing, no cyanosis, and no peripheral lymphadenopathy. BP - 90/60 $\mathrm{mmHg}$, pulse rate $46 / \mathrm{min}$, temperature $-96^{\circ} \mathrm{F}, \mathrm{SpO}_{2}-93 \%$, and inspection of the cervical region showed no enlarged thyroid gland/goiter.

Systemic examination: Cardiovascular system $-\mathrm{S}_{1} \mathrm{~S}_{2}$ normal, respiratory system - bilateral air entry present, abdomen - soft, no organomegaly, central nervous system - no sensory and motor deficits, and Glasgow Coma Scale $-12 / 15$. On admission, she was found to have decreased sodium levels and treated accordingly. Her condition worsened after 12 $\mathrm{h}$ of admission, she was shifted to intensive care unit where orotracheal intubation done and she was supported by mechanical ventilation. She was diagnosed with myxoedema coma with severe hypothyroidism and electrolyte imbalance (Table 1).

\section{OTHER REPORTS}

- Arterial blood gas - analysis showed respiratory acidosis

- Electrocardiogram - bradycardia
- Chest X-ray - mild pericardial effusion

- Ultrasound abdomen-Normal study

- Computed tomography brain - normal study.

\section{POSITIVE FINDINGS PERTAINING TO THIS CASE}

- Anemia

- Elevated transaminases

- Hypoglycemia

- Hyponatremia

- Hypokalemia

- Hypochloremia

- Respiratory acidosis.

\section{TREATMENT}

This patient was initially treated for electrolyte imbalance with in vitro fertilization - 3\% NS. After one of admission, she was found to have severe hypothyroidism with many physiological decompensations. Two units of packed cells were transfused. Sodium and potassium replacement were given. Intravenous (IV) antibiotics were given. This patient's serum thyroid-stimulating hormone (TSH) was high and her free T3 was very low, which indicates primary hypothyroidism rather than pituitary dysfunction. There was no available IV thyroxine (in hand), and the patient was administered higher dose (double dose) of oral regimen.

Thyroxine (T4) was administered through Ryle's tube as a bolus dose of $300 \mu \mathrm{g}$ followed by $300 \mu \mathrm{g}$ the next 3 days. IV hydrocortisone was administered as a bolus dose of $100 \mathrm{mg}$ followed by $50 \mathrm{mg} 4$ times a day. The patient condition improved. She was extubated. She was transferred to general medicine female ward from where she was discharged. She was advised to come for periodic check-up and to take hypothyroid drugs regularly.

\section{DISCUSSION}

Untreated severe hypothyroidism results in myxoedema coma, which is a life-threatening condition causing many physiological decompensations, including mental changes $[1,2,4,7]$. Elderly women with long-standing, undiagnosed, or undertreated hypothyroidism 
Table 1: Laboratory investigations

\begin{tabular}{|c|c|c|c|}
\hline Parameters & On admission & After 3 days of treatment & After 3 days of treatment \\
\hline Hemoglobin & $8.6 \mathrm{gm} / \mathrm{dl}$ & $10.2 \mathrm{gm} / \mathrm{dl}$ & $10.8 \mathrm{gm} / \mathrm{dl}$ \\
\hline Hematocrit (\%) & 33 & 40 & 44 \\
\hline RBC count & 2.4 millions $/ \mathrm{mm}^{3}$ & 4.1 millions $/ \mathrm{mm}^{3}$ & 4.1 millions $/ \mathrm{mm}^{3}$ \\
\hline Total count & 9750 cells $/ \mathrm{mm}^{3}$ & 5600 cells $/ \mathrm{mm}^{3}$ & 4350 cells $/ \mathrm{mm}^{3}$ \\
\hline Kidney function test: Blood urea & $23 \mathrm{mg} / \mathrm{dl}$ & $26 \mathrm{mg} / \mathrm{dl}$ & $33 \mathrm{mg} / \mathrm{dl}$ \\
\hline Serum creatinine & $0.8 \mathrm{mg} / \mathrm{dl}$ & $0.9 \mathrm{mg} / \mathrm{dl}$ & $1.0 \mathrm{mg} / \mathrm{dl}$ \\
\hline Fasting blood sugar & $69 \mathrm{mg} / \mathrm{dl}$ & $74 \mathrm{mg} / \mathrm{dl}$ & $89 \mathrm{mg} / \mathrm{dl}$ \\
\hline Direct bilirubin & $0.4 \mathrm{mg} / \mathrm{dl}$ & $0.5 \mathrm{mg} / \mathrm{dl}$ & $0.5 \mathrm{mg} / \mathrm{dl}$ \\
\hline Indirect bilirubin & $0.8 \mathrm{mg} / \mathrm{dl}$ & $0.6 \mathrm{mg} / \mathrm{dl}$ & $0.6 \mathrm{mg} / \mathrm{dl}$ \\
\hline SGOT & $112 \mathrm{IU} / \mathrm{L}$ & $97 \mathrm{IU} / \mathrm{L}$ & $89 \mathrm{IU} / \mathrm{L}$ \\
\hline SGPT & $86 \mathrm{IU} / \mathrm{L}$ & $78 \mathrm{IU} / \mathrm{L}$ & $74 \mathrm{IU} / \mathrm{L}$ \\
\hline Alkaline phosphate & $110 \mathrm{IU} / \mathrm{L}$ & $108 \mathrm{IU} / \mathrm{L}$ & $112 \mathrm{IU} / \mathrm{L}$ \\
\hline GGT & $54 \mathrm{IU} / \mathrm{L}$ & $50 \mathrm{IU} / \mathrm{L}$ & $52 \mathrm{IU} / \mathrm{L}$ \\
\hline Total protein & $6.3 \mathrm{gm} / \mathrm{dl}$ & $6.6 \mathrm{gm} / \mathrm{dl}$ & $7.1 \mathrm{gm} / \mathrm{dl}$ \\
\hline Albumin & $3.2 \mathrm{gm} / \mathrm{dl}$ & $3.6 \mathrm{gm} / \mathrm{dl}$ & $4.2 \mathrm{gm} / \mathrm{dl}$ \\
\hline Serum electrolytes: Sodium & $116.9 \mathrm{mEq} / \mathrm{L}$ & $124.6 \mathrm{mEq} / \mathrm{L}$ & $133.8 \mathrm{mEq} / \mathrm{L}$ \\
\hline Potassium & $2.96 \mathrm{mEq} / \mathrm{L}$ & $3.01 \mathrm{mEq} / \mathrm{L}$ & $3.67 \mathrm{mEq} / \mathrm{L}$ \\
\hline Chloride & $81.6 \mathrm{mEq} / \mathrm{L}$ & $93.4 \mathrm{mEq} / \mathrm{L}$ & $101.3 \mathrm{mEq} / \mathrm{L}$ \\
\hline Thyroid function test: Free $\mathrm{T}_{3}$ & $0.01 \mathrm{pg} / \mathrm{ml}$ & $1.47 \mathrm{pg} / \mathrm{ml}$ & $2.7 \mathrm{pg} / \mathrm{ml}$ \\
\hline Free $\mathrm{T}_{4}$ & $0.37 \mathrm{ng} / \mathrm{dl}$ & $0.93 \mathrm{ng} / \mathrm{dl}$ & $1.1 \mathrm{ng} / \mathrm{dl}$ \\
\hline $\mathrm{TSH}^{4}$ & $>150 \mu \mathrm{IU} / \mathrm{ml}$ & $89 \mu \mathrm{IU} / \mathrm{ml}$ & $52 \mu \mathrm{IU} / \mathrm{ml}$ \\
\hline
\end{tabular}

TSH: Thyroid-stimulating hormone; RBC: Red blood cell; GGT: Gamma-glutamyl transferase

were commonly affected by myxoedema coma whose present condition is triggered by significant additional stress, such as infection, a systemic disease, certain medications, and exposure to a cold environment [8]. The clinical features of myxoedema coma are altered level of consciousness, bradycardia, hypothermia, hypoglycemia, hypotension, hyponatremia, concurrent (precipitating) illness, and anemia. This patient was found to have almost all clinical features of myxoedema coma. Coexisting adrenal insufficiency in hypothyroidism causes hypoglycemia. Hyponatremia, which is the very common presentation in myxoedema coma is due to reduced levels of $\mathrm{Na}+\mathrm{K}+\mathrm{ATPa} e$, decreased sodium reabsorption, and impaired free water excretion. There are high chances of cardiac disease in hypothyroid patients with raised inflammation [9-14]. This patient had hypotension and severe bradycardia, reduced cardiac contractility which are common in hypothyroidism. Thyroid hormone replacement reverses these heart changes [9]. Hypoventilation and respiratory acidosis are due to respiratory depression. Furthermore, macroglossia or myxoedema of the larynx can lead to airway obstruction. Ventilatory support is needed in some patients, and respiratory depression can be reversed after 3-6 months of treatment [4]. Poor prognostic factors include persistent hypothermia that is unresponsive to $72 \mathrm{~h}$ of therapy, advanced age, bradycardia $(<44$ beats/min), sepsis, myocardial infarction, and hypotension. Predictive values of survival are the patient's level of consciousness at admission and his/her score on the Glasgow Coma Scale and on the acute physiology and chronic health evaluation II [10]. Three different regimens for treating myxoedema coma have been suggested [11]: (1) IV or oral T4, (2) IV T3, or (3) a combination of T4 and T3. It is advisable to give T4 intravenously due to unpredictability of oral route absorption [12].

This patient's serum TSH was high and her free T3 was very low, which indicates primary hypothyroidism rather than pituitary dysfunction. There was no available IV thyroxine, so the patient was administered higher dose (double dose) of oral regimen.

Thyroxine (T4) was administered through Ryle's tube as a bolus dose of $300 \mu \mathrm{g}$ followed by $300 \mu \mathrm{g}$ the next 3 days. IV hydrocortisone was administered as a bolus dose of $100 \mathrm{mg}$ followed by $50 \mathrm{mg} 4$ times a day. It is generally advised to treat patients with myxoedema crisis with steroids because of possibility of coexistent adrenal insufficiency and also because thyroid hormone therapy increases cortisol clearance from the body. Apart from T4 and steroid administration, ventilatory support, IV fluids/vasopressors to correct hypotension, passive rewarming, correction of hypoglycemia, correction of hyponatremia, correction of anemia, and treatment of underlying infection were also taken care of.

\section{CONCLUSION}

Myxoedema coma is a rare but a very important medical emergency with an increased death rate. Correct diagnosis and early thyroid hormone replacement are required. In case of unavailability of laboratory results, glucocorticoid administration is the main drug in the treatment of hypothyroidism. Supportive measures are of highly important in the treatment of myxoedema coma.

\section{AUTHORS' CONTRIBUTIONS}

1. Laboratory values interpretation and case discussion

2. Manuscript preparation and correspondence.

\section{CONFLICTS OF INTEREST}

None.

\section{ETHICAL CLEARANCE}

Obtained.

\section{CONSENT}

Informed consent obtained from patient.

\section{REFERENCES}

1. Titinalli JE, Kelen GD, Stapczynski JS. Hypothyroidism and myxedema coma. In: Seils A, Fernando N, Watt M, editors. Emergency Medicine; A Comprehensive Study Guide. $6^{\text {th }}$ ed. New York: McGraw-Hills Inc.; 2004. p. 1313-5.

2. Wall CR. Myxoedema coma: Diagnosis and treatment. Am Fam Physician 2000;62:2485-90.

3. Fliers E, Wiersinga WM. Myxoedema coma. Rev Endocr Metab Disord 2003;4:137-41.

4. Kwaku MP, Burman KD. Myxoedema coma. J Intensive Care Med 2007;22:224-31

5. Klubo-Gwiezdzinska J, Wartofsky L. Thyroid emergencies. Med Clin 
North Am 2012;96:385-403.

6. Elena C. Myxoedema Coma or Crisis; 2014. Available from: http:// www.emedicine.medscape.com/ article/123577-overview. [Last accessed on 2015 May 04]

7. Rosen M. Hypothyroidism. In: Marx J, editor. Rosen's Emergency Medicine: Concepts and Clinical Practice. $5^{\text {th }}$ ed. St. Louis, MO: Mosby Inc.; 2002. p. 1774-9.

8. Available from: http://www.misc.medscape.com/pi/iphone/ medscapeapp/html/A123577-business.html.

9. Shenoy MM, Goldman JM. Hypothyroid cardiomyopathy: Echocardiographic documentation of reversibility. Am J Med Sci 1987;294:1-9

10. Rodríguez I, Fluiters E, Pérez-Méndez LF, Luna R, Páramo C,
GarcíaMayor RV. Factors associated with mortality of patients with myxoedema coma: Prospective study in 11 cases treated in a single institution. J Endocrinol 2004;180:347-50.

11. Beynon J, Akhtar S, Kearney T. Predictors of outcome in myxoedema coma. Crit Care 2008;12:111

12. Holvey DN, Goodner CJ, Nicoloff JT, Dowling JT. Treatment of myxedema coma with intravenous thyroxine. Arch Intern Med 1964;113:89-96.

13. Gupta G, Sharma P, Kumar P, Sharma R. Scope of inflammatory markers in subclinical hypothyroidism. Asian J Pharm Clin Res 2015;8:24-7.

14. Gupta G, Sharma P, Kumar P, Sharma R. Cardiovascular risk in patients with mild to severe subclinical hypothyroidism. Asian J Pharm Clin Res 2016;9:183-5 